\title{
Functionalization of anthracene: A selective route to brominated 1,4-anthraquinones
}

\author{
Kiymet Berkil Akar ${ }^{1}$, Osman Cakmak ${ }^{* 1}$, Orhan Büyükgüngör ${ }^{2, \S}$ \\ and Ertan Sahin $3, \S$
}

\section{Full Research Paper}

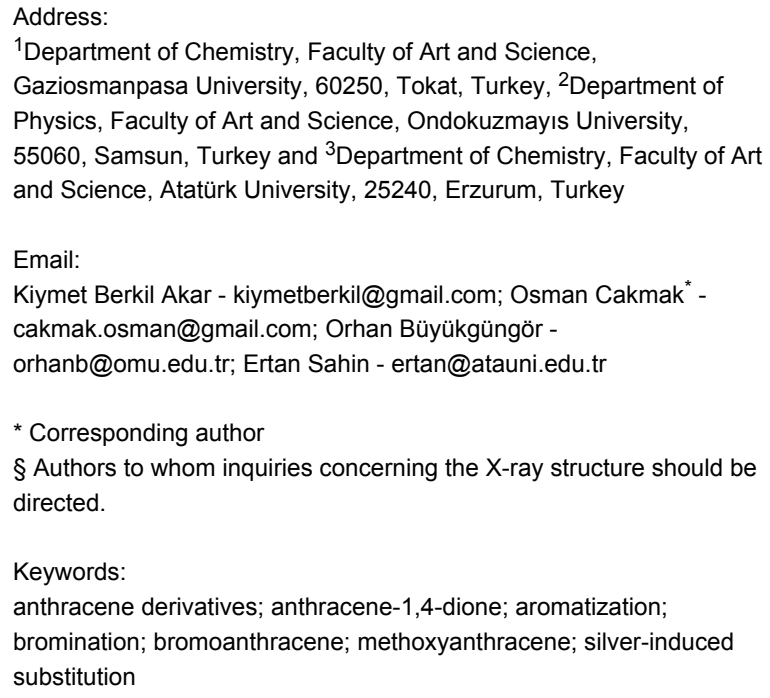

\author{
Beilstein J. Org. Chem. 2011, 7, 1036-1045. \\ doi:10.3762/bjoc. 7.118 \\ Received: 29 March 2011 \\ Accepted: 08 July 2011 \\ Published: 29 July 2011 \\ Associate Editor: M. S. Sherburn \\ (C) 2011 Berkil Akar et al; licensee Beilstein-Institut. \\ License and terms: see end of document.
}

\begin{abstract}
Efficient and stereoselective syntheses are described for the preparation of 2,3,9,10-tetrabromo-1,4-dimethoxy-1,2,3,4-tetrahydroanthracenes 7, 8 and the corresponding 1,4-diol 17 by silver ion-assisted solvolysis of hexabromotetrahydroanthracene $\mathbf{6}$. Basepromoted aromatization of $\mathbf{7}$ and $\mathbf{8}$ afforded synthetically valuable tribromo-1-methoxyanthracenes $\mathbf{1 0}$ and $\mathbf{1 1}$. The reaction of $\mathbf{1 7}$ with sodium methoxide generated tribromodihydroanthracene-1,4-diol 27, whose oxidation with PCC gave 2,9,10-tribromoanthracene-1,4-dione (28). Therefore a selective and efficient method was developed for the preparation of compound $\mathbf{2 8}$ starting from 9,10-dibromoanthracene (1), in a simple four-step process. Compounds $\mathbf{1 0}$ and 11, and diol $\mathbf{2 7}$ constitute key precursors for the preparation of functionalized substituted anthracene derivatives that are difficult to prepare by other routes. The studies also reveal the broad range of reactivity and selectivity of the stereoisomeric anthracene derivatives.
\end{abstract}

\section{Introduction}

Our sustained interest in benzenoid aromatic compounds with high bromine content has led to the development of a regio- and stereoselective bromination method for aromatic compounds. Recently, we demonstrated the selective bromination of 9,10-di- bromoanthracene (1) to give hexabromides $\mathbf{2}$ and $\mathbf{3}$ (Scheme 1) [1]. These studies revealed that hexabromides $\mathbf{2}$ and $\mathbf{3}$ are good precursors for the preparation of anthracene oxides and methoxyanthracene derivatives by silver ion-induced substitution. 


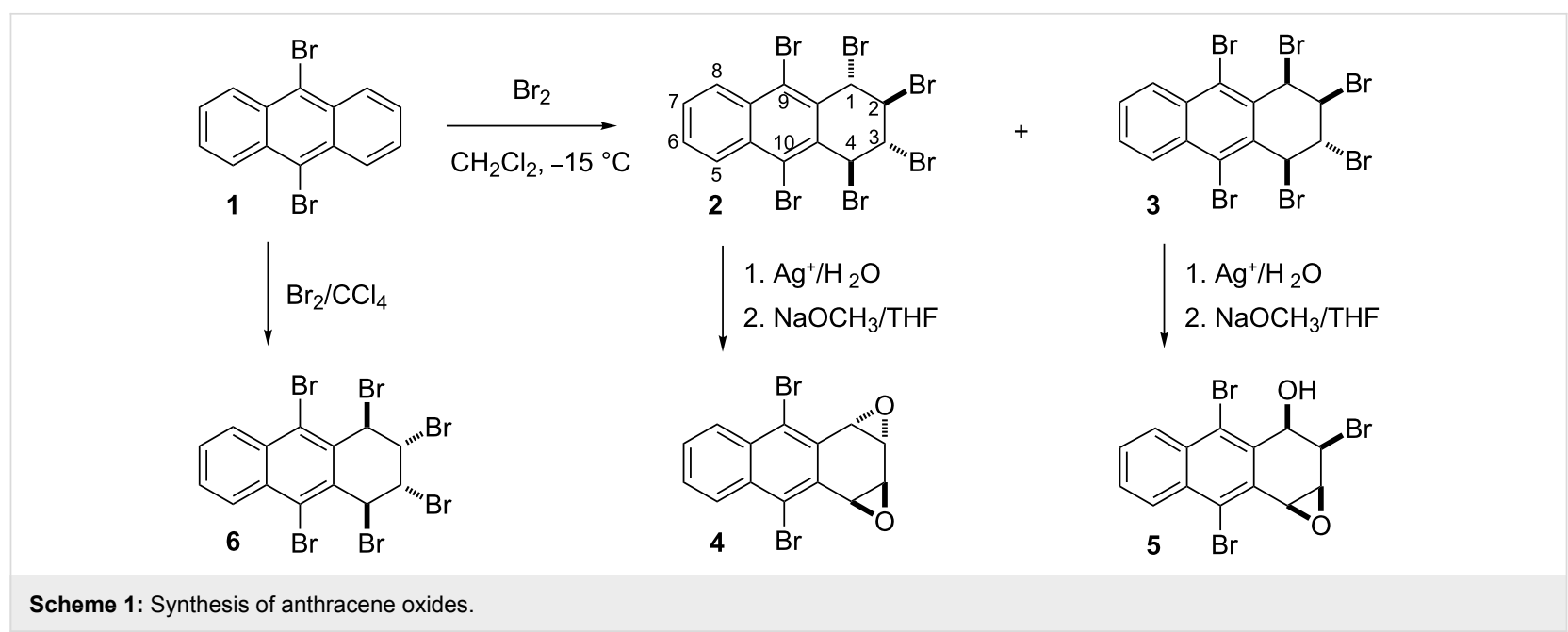

Our previous studies revealed that aromatization of hexabromides $\mathbf{2}$ and $\mathbf{3}$ showed complete selectivity both in their aromatization and silver-assisted solvolysis. On the other hand, most recently, we have developed an efficient stereoselective method to prepare hexabromide $6[2,3]$ and opened up an efficient synthetic strategy for the synthesis of 3,9,10-tribromoanthracenes [2]. As an extension of this work, we report on new methoxy and hydroxy derivatives of anthracene, whose further transformation generates synthetically important novel anthracene derivatives. We also report an effective synthetic route to 1,4dione 28 starting from 9,10-dibromoanthracene (1) in four steps. The compounds constitute potentially important keys for the synthesis of pharmaceutical chemicals [4-7], natural products [8,9] and donor properties [10,11]. Anthraquinone 28 may be used as precursor for 9,10-disubstituted-2-phenoxyanthracene-1,4-dione derivatives that are difficult to synthesize by other routes. There has been much interest in the preparation of phenoxy-1,4-anthraquinone derivatives due to their antitrypanosomal activity. Bolognesi et al. designed and synthesized a small library of 2-phenoxy-1,4-anthraquinone derivatives, all of which showed inhibitory activity toward either Trypanosoma or Leishmania species [12].

\section{Results and Discussion}

A solution of hexabromide $\mathbf{6}$ in dry methanol was treated with two equivalents of silver perchlorate at room temperature for two days in the dark. The reaction resulted in the formation of dimethoxy compounds $\mathbf{7}$ and $\mathbf{8}$ in a ratio of 37:63 as assigned by ${ }^{1} \mathrm{H}$ NMR (Scheme 2). Although the methanolysis was repeated several times, the product ratio remained almost the same. The compounds were separable by column chromatography and were isolated in 29 and $44 \%$ yield for $\mathbf{7}$ and $\mathbf{8}$, respectively.

There are three possible stereoisomers that can be formed in the reaction, however, it was difficult to distinguish the exact stereochemistry of symmetrical compounds $\mathbf{7}$ and $\mathbf{8}$ by NMR. Therefore, X-ray diffraction analysis was also carried out for 7 . The study confirmed the structure of 7 without any ambiguity (Figure 1).

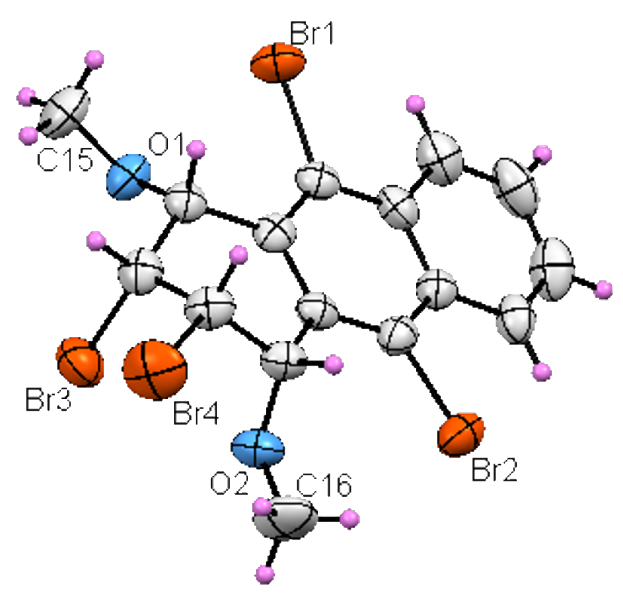

Figure 1: Molecular structure of compound 7. Displacement ellipsoids are shown at $40 \%$ probability level.

Proton and carbon NMR studies indicated that tetrabromide $\mathbf{8}$ has an asymmetric structure. There is only one possible isomeric structure available for asymmetric dimethoxides. In the NMR spectrum of compound $\mathbf{8}$ all of the signals are multiplets, except for the two methoxy groups that appear as singlets ( $\delta 4.05$ and 3.66) and the doublet of $\mathrm{H} 1(J=2.4 \mathrm{~Hz})$. Resonances of aryl protons ( $\delta 8.45 \mathrm{ppm}$ for $\mathrm{H} 5$ and $\mathrm{H} 8 ; \delta 7.66 \mathrm{ppm}$ for $\mathrm{H} 6$ and $\mathrm{H7}$ ) are in accordance with the suggested structure. The aliphatic protons appear to be at $\delta 5.38(\mathrm{~d}, J=2.4 \mathrm{~Hz}, \mathrm{H} 1)$, $\delta 5.15(\mathrm{~m}, \mathrm{H} 4$ and $\mathrm{H} 2)$ and $\delta 4.83(\mathrm{~m}, \mathrm{H} 3)$, respectively. In particular, a 15-line (in fact 16, one of which is overlapped) ${ }^{13} \mathrm{C}$ NMR spectrum supports the asymmetry in the molecule. 
<smiles>CO[C@H]1c2c(c(Br)c3ccccc3c2Br)C(Br)[C@@H](Br)[C@H](Br)[C@H]1Br</smiles><smiles>Brc1c2c(c(Br)c3ccccc13)C(Br)[C@@H](Br)[C@@H](Br)C2Br</smiles>

6 $\mathrm{Br}_{2} / \mathrm{h} v$ $\mathrm{CCl}_{4}, 25^{\circ} \mathrm{C}$<smiles>Brc1c2ccccc2c(Br)c2ccccc12</smiles>

1<smiles>CO[C@H]1c2c(c(Br)c3ccccc3c2Br)[C@H](OC)[C@@H](Br)[C@@H]1Br</smiles>

8, $38.15 \mathrm{~kJ} / \mathrm{mol}$

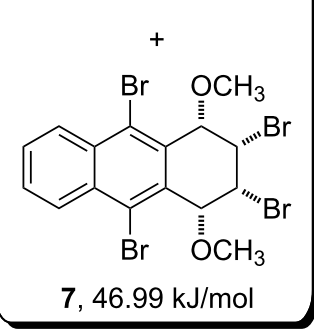
$\mathrm{CH}_{3} \mathrm{ONa} / \mathrm{THF}$<smiles>COc1ccc(OC)c2c(Br)c3ccccc3c(Br)c12</smiles>

$13,26.69 \mathrm{~kJ} / \mathrm{mol}$

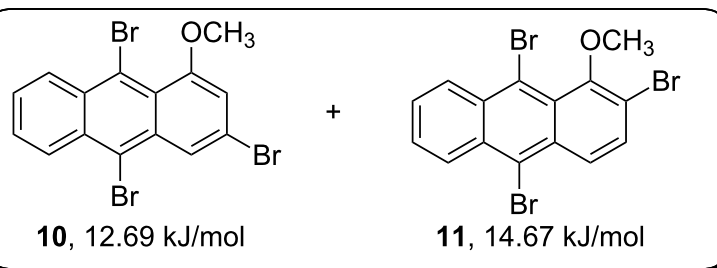

$\mathrm{CH}_{3} \mathrm{ONa} / \mathrm{THF}$<smiles>COC1c2c(c(Br)c3ccccc3c2Br)C(OC)C(Br)C1Br</smiles>

Scheme 2: Synthesis of methoxyanthracenes 10 and 11.

Formation of both, $\mathbf{7}$ and $\mathbf{8}$ can be explained from the initially formed product 9 . In the second step, a silver-promoted $\mathrm{S}_{\mathrm{N}} 1$ reaction of 9 results in the two compounds. Compound 7, with all four substituents on the same face of the ring, possesses increased steric energy, which explains why compound 7 is obtained as minor isomer (Scheme 2).

After successful isolation of $\mathbf{7}$ and $\mathbf{8}$, which both have the required skeletal arrangement and functionality to permit the easy introduction of two double bonds, the compounds were subjected to base-induced elimination. In separate reactions, both aromatizations afforded the same product mixture, i.e., 1-methoxy-3,9,10-tribromoanthracene (10) and 1-methoxy2,9,10-tribromoanthracene (11), but in different ratios. The ratios of compounds $\mathbf{1 0}$ and $\mathbf{1 1}$ are 64:36 from $\mathbf{7}$ and 45:55 from 8 , respectively (Scheme 2 ). The compounds were easily sep- arated by column chromatography and are readily crystallizable materials. Structure assignment for compounds $\mathbf{1 0}$ and $\mathbf{1 1}$ was carried out by comparison with authentic compounds [1].

To elucidate the mechanistic details and to explore the origin of selectivity, we also investigated the reaction of 1,4-dimethoxy compound 8 with one equivalent of sodium methoxide (Scheme 3). The reaction afforded a mixture of 14, 11 and $\mathbf{1 0}$ in a ratio of 56:13:1, as calculated by integration of the ${ }^{1} \mathrm{H}$ NMR signals of the methoxy groups, besides the remaining starting material (70\% conversion). After chromatography, the major product 14 was isolated in $41 \%$ yield. The ${ }^{1} \mathrm{H}$ NMR spectrum of 14 consisted of seven signal groups. An AA'BB'-like signal system of aryl protons appeared at $\delta 8.48$ and $\delta 7.70$. While the resonance of $\mathrm{H} 1$ was at $5.82 \mathrm{ppm}$ as a singlet, the resonance of $\mathrm{H} 4$ at $5.44 \mathrm{ppm}$ appeared as a doublet of doublet $(J=4 \mathrm{~Hz}$ and 
<smiles>COC1c2c(c(Br)c3ccccc3c2Br)C(OC)[C@@H](Br)[C@@H]1Br</smiles>

$\mathrm{CH}_{3} \mathrm{ONa}$

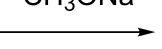

$\mathrm{Br} \quad \mathrm{OCH}_{3}$<smiles>COc1c(Br)ccc2c(Br)c3ccccc3c(Br)c12</smiles><smiles>CO[C@]1(C)C(Br)=C[C@@H](CCCO)c2c1c(Br)c1ccccc1c2Br</smiles><smiles>COc1cc(Br)c(OC)c2c(Br)c3ccccc3c(Br)c12</smiles><smiles>CC(C)(C)O</smiles><smiles>COc1cc(Br)cc2c(Br)c3ccccc3c(Br)c12</smiles>

Scheme 3: The reaction mechanism for the formation of methoxyanthracenes $\mathbf{1 0}$ and $\mathbf{1 1 .}$

$J_{1,4}=2 \mathrm{~Hz}$ ). The resonance of olefinic $\mathrm{H} 3$ was observed at $6.86 \mathrm{ppm}$ as a doublet $(J=4.0 \mathrm{~Hz})$. The singlets of methoxy signals were at $\delta 3.23$ and $\delta 2.88$. The ${ }^{13} \mathrm{C}$ NMR spectrum of the compound consisted of twelve signals of aryl and double bond carbons; two $\mathrm{sp}^{3}$ carbons with methoxy groups $(\delta 76.0$ and $\delta 74.4)$ and two methoxy carbons ( $\delta 53.9$ and $\delta 50.9)$.

An unusual mechanism for the formation of $\mathbf{1 4}$ from $\mathbf{8}$ is summarized in Scheme 3, which indicates that the base attacks on both $\mathrm{H} 1$ and $\mathrm{H} 4$ in tribromide $\mathbf{1 4}$ were followed by an elimination to provide compounds $\mathbf{1 0}$ and $\mathbf{1 1}$. The formation of compound $\mathbf{1 3}$, by elimination of two mol of $\mathrm{HBr}$, was prevented, probably due to the enormously increased strain energy between the bulky groups of methoxy and bromine at the $\gamma$-gauche posi- tions, C1/C4 and C9/C10, respectively (Scheme 2) [13] . Additionally, the single crystal X-ray crystallographic data for 7 illustrates the sterically crowded environment of $\mathrm{H} 1$ and $\mathrm{H} 4$, in which base attachment is hindered, and which shows the axiallike orientation of $\mathrm{H} 1$ and $\mathrm{H} 4$ and the equatorial-like orientation of methoxy groups in $\mathrm{C} 1$ and $\mathrm{C} 4$. Therefore, we assume that proper diaxial configuration of $\mathrm{H} 2$ and $\mathrm{Br} 3$ in compounds 7 and $\mathbf{8}$ induces E2 elimination to give compound 14 (Figure 1).

For further functionalization of the anthracene skeleton, hexabromide 6 was subjected to silver ion-assisted hydrolysis in aqueous acetone. Interestingly, the substitution resulted in the stereoselective formation of product 17 in $80 \%$ yield (Scheme 4). Mass spectral analysis of compound 17 confirmed<smiles>Brc1c2c(c(Br)c3ccccc13)C(Br)C(Br)C(Br)C2Br</smiles>
$\mathrm{AgClO}_{4} / \mathrm{H}_{2} \mathrm{O} \downarrow \begin{aligned} & \text { acetone, } 25^{\circ} \mathrm{C} \\ & 2 \mathrm{~d} \text {, dark }\end{aligned}$<smiles>OC1c2c(c(Br)c3ccccc3c2Br)[C@@H](O)[C@H](Br)[C@H]1Br</smiles>

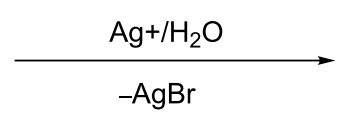<smiles>OC1c2c(c(Br)c3ccccc3c2Br)C(Br)C(Br)C1Br</smiles>

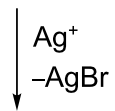<smiles>CCCC</smiles>

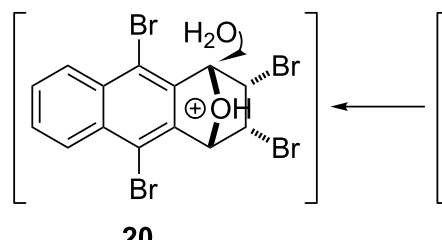

20<smiles>OC1C[C@H](Br)[C@@H](Br)c2c1c(Br)c1ccccc1c2Br</smiles> 
the molecular signal at $m / z 413$ and the ${ }^{1} \mathrm{H}$ NMR spectrum indicates its asymmetry. The ${ }^{13} \mathrm{C}$ NMR spectrum also confirms the asymmetric structure consisting of ten $\mathrm{sp}^{2}$ carbon signals (six quaternary and four methine carbons) and four $\mathrm{sp}^{3}$ carbon signals. It is obvious, that there is only one possible asymmetric isomeric structure of $\mathbf{1 7}$ due to the retention of the configuration of the bromines on the $\mathrm{C} 2$ - and $\mathrm{C} 3$-atoms. $\mathrm{H} 1$ and $\mathrm{H} 4$ protons can be easily identified due to their coupling with the hydroxy groups $\left(J_{1, \mathrm{OH}}=4.0 ; J_{4, \mathrm{OH}}=8.4 \mathrm{~Hz}\right)$. A comparison of the chemical shifts and coupling constants with the products obtained in previous studies [1] is helpful for the identification of isomeric structures. The resonances of benzylic protons (H1 and H4) shift to lower fields than those of $\mathrm{H} 2$ and H3, as shown in our previous similar examples.

In the proton NMR spectrum, the signals at $\delta 5.90$ and $\delta 5.44$ were assigned to $\mathrm{H} 1$ and $\mathrm{H} 4$, respectively. The resonance of $\mathrm{H} 4$ is a doublet of a doublet at $\delta 5.44(\mathrm{~m})$. Therefore the doublet at $\delta 3.10$ belongs to $\mathrm{C} 4-\mathrm{OH}\left(J_{4, \mathrm{OH}}=8.4 \mathrm{~Hz}\right)$. H1 resonates as a multiplet at $\delta 5.90$ due to the nearly identical coupling constant value $\left(J_{1, \mathrm{OH}}=4 \mathrm{~Hz}\right)$. The hydroxy group $(\mathrm{C} 1-\mathrm{OH})$ appears at $\delta$ 2.90 as a doublet $(J \approx 4 \mathrm{~Hz})$. Finally, $\mathrm{H} 2$ and $\mathrm{H} 3$ resonate at $\delta$ 4.79 and $\delta 5.26(J<<4 \mathrm{~Hz})$, respectively. The resonances of $\mathrm{H} 5$ and $\mathrm{H} 8$ at $\delta 8.49$ and $\delta 8.41$ are two different multiplets, while those of $\mathrm{H} 6$ and $\mathrm{H} 7$ are a multiplet at $\delta 7.71$.

Finally, X-ray analysis of the compound was performed and the exact configuration was proved to be dihydroxy 17 (Figure 2).

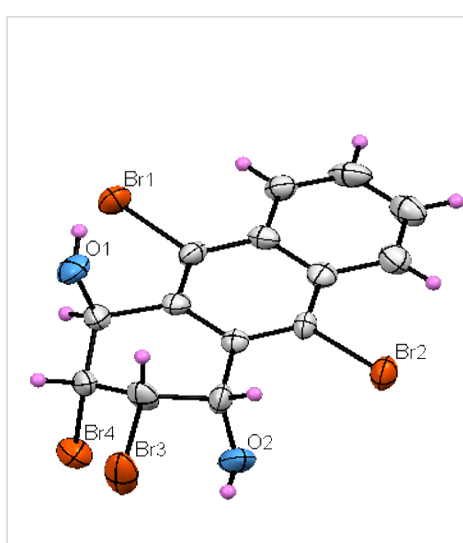

a)

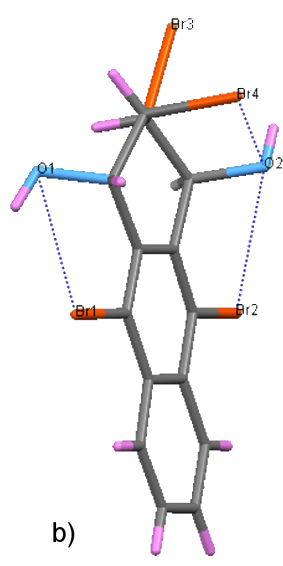

b)

Figure 2: a) X-ray ORTEP plot of compound 17. Displacement ellipsoids are shown at $40 \%$ probability level. b) X-ray structure of 17 showing intramolecular interactions.

The stereoselective formation of $\mathbf{1 7}$ can be explained by the neighboring-group participation, as shown in Scheme 4. We assume that cis orientation of bromine atoms in $\mathrm{C} 2$ and $\mathrm{C} 3$ induces the formation of a bridged-oxonium ion $\mathbf{2 0}$ as an intermediate of 17.

Hydrolysis of hexabromide 6 can lead to three halohydrines (17, 21 and 22), two of which are symmetric (Scheme 5). Dihalohydrine $\mathbf{1 7}$ is expected to be a good precursor to corresponding arene oxides $\mathbf{2 3}$ as shown in our previous studies (Scheme 1 and<smiles>OC1c2c(c(Br)c3ccccc3c2Br)[C@H](O)[C@H](Br)[C@H](Br)[C@H]1Br</smiles>

$17,13.75 \mathrm{~kJ} / \mathrm{mol}$<smiles>O[C@H]1c2c(c(Br)c3ccccc3c2Br)[C@@H]2O[C@H]2[C@H](Br)[C@H]1Br</smiles><smiles>O[C@H]1c2c(c(Br)c3ccccc3c2Br)[C@H](O)[C@@H](Br)[C@H]1Br</smiles>

21, $19.92 \mathrm{~kJ} / \mathrm{mol}$<smiles>CC1C(O)c2c(c(Br)c3ccccc3c2Br)C2OC2C1Br</smiles><smiles>OC1c2c(c(Br)c3ccccc3c2Br)C(O)[C@@H](Br)C1Br</smiles>

24<smiles>OC1c2c(c(Br)c3ccccc3c2Br)C(O)[C@H](Br)C(Br)[C@H]1Br</smiles>

22, $12.00 \mathrm{~kJ} / \mathrm{mol}$<smiles>OC1c2c(Br)cccc2C2OC2C1Br</smiles>

26<smiles>OC1c2cccc(Br)c2C(O)[C@@H](Br)C1Br</smiles>

25

Scheme 5: Base-promoted reaction of the dihydroxides and formation of the epoxides. 

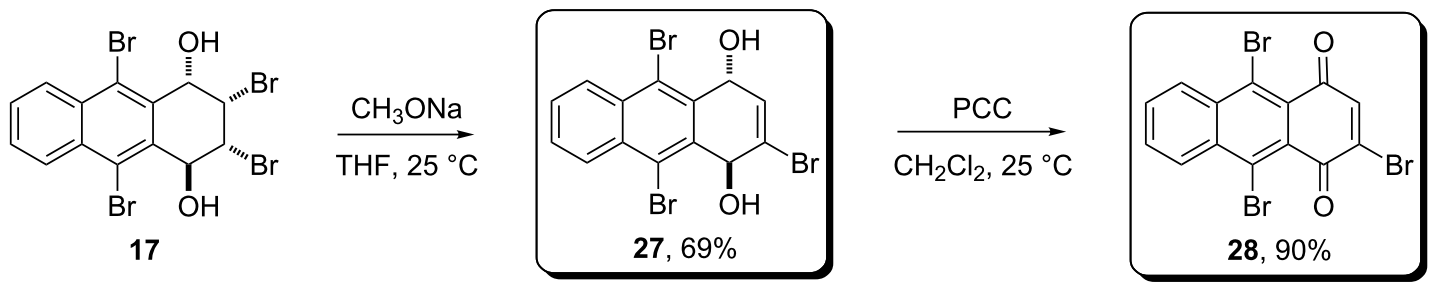

Scheme 6: Synthesis of compounds 27 and 28

Scheme 5) [1,14-16]. Therefore, one or two equivalents of sodium methoxide were applied to $\mathbf{1 7}$ and the reaction resulted in the formation of $\mathbf{2 7}$ contrary to the expected epoxide $\mathbf{2 3}$ or any aromatized products (Scheme 6). In our earlier study, the $\mathrm{X}$-ray packing structure of tetralin oxide $\mathbf{2 6}$ produced from the corresponding halohydrine $\mathbf{2 5}$, shows the existence of hydrogen bonding between the hydroxy and the epoxy group, which has the same stereochemistry as that of compound $5[1,14,15]$ Thus, the fact that compound $\mathbf{2 3}$ was not obtained from $\mathbf{1 7}$ can be attributed to the absence of hydrogen bonding due to the anti-orientation of the substituents in $\mathbf{2 3}$, although compound $\mathbf{2 3}$ is energetically more favourable than the corresponding compound 5 .

The structure of compound $\mathbf{2 7}$ was determined by MS, IR, and ${ }^{1} \mathrm{H}$ and ${ }^{13} \mathrm{C}$ NMR. The mass spectrum of compound 27 gave a [M-2OH] ${ }^{+}$peak at $m / z 413$ corresponding to the formula and the IR spectrum showed a hydroxy band at 3540 and $3338 \mathrm{~cm}^{-1}$. The ${ }^{1} \mathrm{H}$ NMR spectrum consists of simple signal systems; two aryl signals as multiplets at $\delta 8.42$ for $\mathrm{H} 5$ and $\mathrm{H} 8$, and at $\delta 7.72$ for $\mathrm{H} 6$ and $\mathrm{H} 7$, and an olefinic signal at $\delta 6.69$ $(J=4.4 \mathrm{~Hz})$ as a doublet. In addition, the aliphatic signals $\mathrm{H} 1$ and $\mathrm{H} 4$ appear at $\delta 5.80\left(\mathrm{~d}, J_{1, \mathrm{OH}}=6 \mathrm{~Hz}\right)$ and $\delta 5.74(\mathrm{dd}, J=$ $4.4 \mathrm{~Hz}, J_{4, \mathrm{OH}}=6 \mathrm{~Hz}$ ), respectively. The hydroxy protons resonate at $\delta 3.28$ and $\delta 3.22$ as doublets with the same coupling constants. The ${ }^{13} \mathrm{C}$ NMR spectrum with twelve signals is also consistent with the structure of the compound.

It is clear that 1,4-diol 27 should be easily converted to anthracene-1,4-dione 28. Thus, compound $\mathbf{2 7}$ was made to react with PCC at room temperature for 3 days. After the reaction, a simple short silica gel filtration and crystallization from $\mathrm{CH}_{2} \mathrm{Cl}_{2}$, gave the expected 2,9,10-tribromoanthracene-1,4dione (28) in high yield (90\%) (Scheme 6). The ${ }^{1} \mathrm{H}$ NMR spectrum of the compound consisted of four signal systems, one of which is a singlet $(8.81, \mathrm{H} 3)$, while the others are multiplets at 8.74 (H8), 8.48 (H5) and 7.84 (H6 and H7). The ${ }^{13} \mathrm{C}$ NMR spectrum confirms the structure with no aliphatic carbon but two carbonyl signals at $\delta 177.0$ and $\delta 174.3$, respectively.

\section{Conclusion}

This report and our previous studies [1,2] demonstrate that the reactivity and selectivity of the stereoisomeric anthracene derivatives strongly depend on both, the reaction conditions and their stereochemistry. For example, although both hydroxy compounds obtained from hexabromides 2 and 3 [1] afforded epoxides $\mathbf{4}$ and $\mathbf{5}$ upon treatment with sodium methoxide (Scheme 1, Scheme 5), dihydroxy compound $\mathbf{1 7}$ produced olefinic compound $\mathbf{2 7}$, whose oxidation gave diketone $\mathbf{2 8}$. We also observed different reactivities towards the base for the hydroxy and the methoxy compounds. For example, the methoxy compounds aromatize to give $\mathbf{1 0}$ and $\mathbf{1 1}$, but the diols convert either to the epoxides by cyclization (Scheme 1 and Scheme 5) or to the alkene by elimination of $1 \mathrm{~mol} \mathrm{HBr}$ (Scheme 6). In addition, however, the base-induced reaction of both the methoxy stereoisomers $\mathbf{7}$ and $\mathbf{8}$, generated from hexabromide $\mathbf{6}$, and of methoxy compound $\mathbf{1 2}$, obtained from hexabromide 2 and $\mathbf{3}$, gave the same compounds $\mathbf{1 0}$ and $\mathbf{1 1}$ by elimination of one mol of $\mathrm{HBr}$ and $\mathrm{CH}_{3} \mathrm{OH}$.

In conclusion, a convenient and effective procedure for the synthesis of dimethoxy $\mathbf{7}$ and $\mathbf{8}$ was developed, where base-mediated elimination yields the synthetically valuable 1-methoxy3,9,10-tribromoanthracene (10) and 1-methoxy-2,9,10- tribromoanthracene (11), which are very useful precursors for the synthesis of many other substituted anthracenes due to the easy substitution of the bromo substituents. It is noteworthy that separation and crystallization of methoxylated bromoanthracenes is relatively easy compared to bromoanthracenes [1], and this offers important advantages for preparative purposes. Additionally, we describe the first isolation and identification of an anthracene-1,4-dione 28 starting from 1,2,3,4,9,10-hexabromo1,2,3,4-tetrahydroanthracene $\mathbf{6}$. The most important advantage is the complete selectivity of each reaction step. Although the reactions described follow simple synthetic methodology, the results are quite appealing. The present procedure is particularly suitable for the preparation of poly-substituted anthracene1,4-dione and pentacene derivatives, in which the bromo substituents enable further functionalization. 
As a consequence, the studies revealed that the reactivity of the anthracene derivatives displays interesting selectivity and appears to provide a simple route to a range of highly functionalized and potentially useful polysubstituted anthracenes.

\section{Experimental}

General: Thin layer chromatography was carried out on Merck $0.255 \mathrm{~mm}$ silica gel $\mathrm{F}_{254}$ analytical aluminum plates and spots were visualized with UV fluorescence at $254 \mathrm{~nm}$. Classic gravity column chromatography was performed using silica gel 60 (70-230 mesh, Merck). Melting points were determined on a Thomas-Hoover capillary melting point apparatus. Solvents were concentrated at reduced pressure. Infrared spectra were obtained from $\mathrm{KBr}$ pellets on a Jasco FT/IR 430 instrument. Mass spectra were recorded on an Agilent 6890 GC System 5973 MSD spectrometer and THERMO FINNIGAN spectrometer under electron impact (EI) conditions. NMR spectra were recorded on a Bruker spectrometer at $400 \mathrm{MHz}$ for ${ }^{1} \mathrm{H}$ and at $100 \mathrm{MHz}$ for ${ }^{13} \mathrm{C}$ NMR.

\section{Reaction of hexabromide $\mathbf{6}$ with $\mathbf{2}$ equiv of silver perchlorate}

To a stirred solution of hexabromide 6 (600 $\mathrm{mg}, 0.915 \mathrm{mmol})$ in dry and freshly distilled methanol $(60 \mathrm{~mL})$ was added silver perchlorate (475 mg, $2.287 \mathrm{mmol}$ ) under an argon atmosphere in the dark. The resulting reaction mixture was stirred magnetically at $\mathrm{rt}$ for $2 \mathrm{~d}$. Reaction progress was monitored by TLC for consumption of the starting material. The silver bromide precipitate was removed by filtration and to the mother liquor was added methylene chloride $(50 \mathrm{~mL})$. The material was washed with water $(4 \times 50 \mathrm{~mL})$ and dried over $\mathrm{Na}_{2} \mathrm{SO}_{4}$. After drying and removal of the solvent, NMR analysis showed two compounds in a ratio of $63: 37$. The residue $(374 \mathrm{mg})$ was purified by column chromatography on silica gel $(20 \mathrm{~g})$ using $n$-hexane as eluent. The first fraction was $\left(1 R^{*}, 2 R^{*}, 3 S^{*}, 4 R^{*}\right)-2,3,9,10-$ tetrabromo-1,4-dimethoxy-1,2,3,4-tetrahydroanthracene $(\mathbf{8})$ : (224 mg, 44\%, colorless crystals). The second fraction was $\left(1 R^{*}, 2 R^{*}, 3 S^{*}, 4 S^{*}\right)$-2,3,9,10-tetrabromo-1,4-dimethoxy-1,2,3,4tetrahydroanthracene (7) (144 mg, 29\%, colorless crystals).

$\left(1 R^{*}, 2 R *, 3 S^{*}, 4 R^{*}\right)-2,3,9,10$-Tetrabromo-1,4-dimethoxy1,2,3,4-tetrahydroanthracene (8) $\mathrm{mp} 160-162{ }^{\circ} \mathrm{C}$ (dichloromethane/hexane); ${ }^{1} \mathrm{H}$ NMR $\left(400 \mathrm{MHz}, \mathrm{CDCl}_{3}\right) \delta 8.45$ $(\mathrm{m}, 2 \mathrm{H}), 7.66(\mathrm{~m}, 2 \mathrm{H}), 5.38(\mathrm{~d}, 1 \mathrm{H}, J=2.4 \mathrm{~Hz}), 5.15(\mathrm{~m}, 2 \mathrm{H})$, $4.83(\mathrm{~m}, 1 \mathrm{H}), 4.05(\mathrm{~s}, 3 \mathrm{H}), 3.66(\mathrm{~s}, 3 \mathrm{H}) ;{ }^{13} \mathrm{C} \mathrm{NMR}(100 \mathrm{MHz}$, $\left.\mathrm{CDCl}_{3}\right) \delta 134.1,133.4,133.3,130.6,129.0,128.9,128.5$, $128.3,128.2,83.5,79.9,64.6,58.9,48.8,48.7$; IR $\left(\mathrm{KBr}, \mathrm{cm}^{-1}\right)$ : 2978, 2927, 2824, 1567, 1540, 1521, 1506, 1478, 1455, 1439, $1404,1371,1353,1331,1275,1250,1331,1201,1181,1158$, 1131, 1079, 1067, 972, 935, 916, 862, 836, 762, 753, 691, 660, $620,602,570,541,478,458$; MS (APCI) $m / z 576.3[\mathrm{M}+$
$\left.\mathrm{NH}_{4}\right]^{+}, 560.1[\mathrm{M}+2 \mathrm{H}]^{+}, 526.6\left[\mathrm{M}-2 \mathrm{OCH}_{3}\right]^{+}, 475.7[\mathrm{M}-\mathrm{Br}$ $-2 \mathrm{H}]^{+}, 445.7\left[\mathrm{M}-\mathrm{OCH}_{3}-\mathrm{Br}+\mathrm{H}\right]^{+}, 395.8[\mathrm{M}-2 \mathrm{Br}-2 \mathrm{H}]^{+}$, $365.8\left[\mathrm{M}-\mathrm{OCH}_{3}-2 \mathrm{Br}\right]^{+}, 335.8\left[\mathrm{M}-2 \mathrm{OCH}_{3}-2 \mathrm{Br}\right]^{+}, 312.2$, 298.3, 284.2, 270.2, 256.1, 242.2, 228.2, 84.1; Anal. calcd for $\mathrm{C}_{16} \mathrm{H}_{14} \mathrm{Br}_{4} \mathrm{O}_{2}$ : C, 34.45; H, 2.53; found: $\mathrm{C}, 34.43$; H, 2.562 .

$\left(1 R^{*}, 2 R *, 3 S^{*}, 4 S^{*}\right)-2,3,9,10$-Tetrabromo-1,4-dimethoxy1,2,3,4-tetrahydroanthracene (7) $\mathrm{mp} 153-154{ }^{\circ} \mathrm{C}$ (dichloromethane/hexane); ${ }^{1} \mathrm{H}$ NMR (400 MHz, $\left.\mathrm{CDCl}_{3}\right) \delta 8.45$ (m, 2H), $7.69(\mathrm{~m}, 2 \mathrm{H}), 5.16(\mathrm{~m}, 2 \mathrm{H}), 4.78(\mathrm{~m}, 2 \mathrm{H}), 3.75(\mathrm{~s}, 6 \mathrm{H})$; ${ }^{13} \mathrm{C} \mathrm{NMR}\left(100 \mathrm{MHz}, \mathrm{CDCl}_{3}\right) \delta 133.4,133.2,129.0,128.5$, 127.3, 79.9, 59.8, 51.2; IR (KBr, $\left.\mathrm{cm}^{-1}\right): 2949,2921,2826$, $1698,1671,1559,1478,1438,1348,1333,1276,1249,1186$, 1161, 1123, 1078, 1002, 973, 941, 911, 860, 831, 776, 761, 728, $677,629,610,582,526,507,473$; MS (APCI) $m / z 526.6[\mathrm{M}-$ $\left.\mathrm{OCH}_{3}\right]^{+}, 494.6\left[\mathrm{M}-2 \mathrm{OCH}_{3}-\mathrm{H}\right]^{+}, 446.7\left[\mathrm{M}-\mathrm{OCH}_{3}-\mathrm{Br}\right]^{+}$, $413.7\left[\mathrm{M}-2 \mathrm{OCH}_{3}-\mathrm{Br}-2 \mathrm{H}\right]^{+}, 396.9[\mathrm{M}-2 \mathrm{Br}-\mathrm{H}]^{+}, 365.8$ $\left[\mathrm{M}-\mathrm{OCH}_{3}-2 \mathrm{Br}\right]^{+}, 335.9\left[\mathrm{M}-2 \mathrm{OCH}_{3}-2 \mathrm{Br}\right]^{+}, 316.0,303.0$, 279.1, 152.0, 79.1, 65.2; Anal. calcd for $\mathrm{C}_{16} \mathrm{H}_{14} \mathrm{Br}_{4} \mathrm{O}_{2}$ : C, 34.45 ; H, 2.53; found: C, 35.57; H, 2.59.

\section{Aromatization of compound 7}

A stirred solution of compound $7(150 \mathrm{mg}, 0.27 \mathrm{mmol})$ in dry and freshly distilled THF $(20 \mathrm{~mL})$ was combined with a solution of sodium methoxide ( $44 \mathrm{mg}, 0.806 \mathrm{mmol}$ ) in freshly distilled THF $(15 \mathrm{~mL})$ under an argon atmosphere. The resulting reaction mixture was magnetically stirred for $12 \mathrm{~h}$ at $25^{\circ} \mathrm{C}$. Ether $(40 \mathrm{~mL})$ was added to the reaction mixture and the resulting precipitate was washed with water $(3 \times 50 \mathrm{~mL})$ and dried over anhydrous sodium sulfate. The solvent was evaporated. ${ }^{1} \mathrm{H}$ NMR of the residue $(0.105 \mathrm{~g}$, total yield: $90 \%)$ showed two products in a ratio of 64:36 for $\mathbf{1 1}$ and $\mathbf{1 0}$, respectively. The residue $(0.105 \mathrm{~g})$ was purified by column chromatography on silica gel ( $40 \mathrm{~g}$ ) using $n$-hexane as eluent. The first fraction was 1-methoxy-3,9,10-tribromoanthracene (10) (22 mg, $19 \%$, yellow crystals). The second fraction was 1-methoxy2,9,10-tribromoanthracene (11) (51 mg, 43\%, yellow crystals).

1-Methoxy-3,9,10-tribromoanthracene (10) $\mathrm{mp} 159-160{ }^{\circ} \mathrm{C}$ (chloroform/hexane); ${ }^{1} \mathrm{H}$ NMR (400 MHz, $\left.\mathrm{CDCl}_{3}\right) \delta 8.80(\mathrm{~m}$, $1 \mathrm{H}), 8.39(\mathrm{~m}, 1 \mathrm{H}), 8.30\left(\mathrm{~d}, J_{2,4}=1.7 \mathrm{~Hz}, 1 \mathrm{H}\right), 7.50(\mathrm{~m}, 2 \mathrm{H})$, $6.83\left(\mathrm{~d}, J_{2,4}=1.7 \mathrm{~Hz}, 1 \mathrm{H}\right), 3.93(\mathrm{~s}, 3 \mathrm{H}) ;{ }^{13} \mathrm{C} \mathrm{NMR}(100 \mathrm{MHz}$, $\left.\mathrm{CDCl}_{3}\right) \delta 156.7,133.1,132.2,131.6,129.4,128.4,128.2$, 127.6, 123.1, 122.9, 122.4, 121.5, 119.4, 109.5, 55.9; IR (KBr, $\left.\mathrm{cm}^{-1}\right): 2956,2925,2854,1618,1596,1540,1523,1457,1427$, $1373,1349,1303,1267,1247,1093,983,923,885,833,815$, 811,744, 549, 437, 410; MS (GC-MS) $m / z 443[\mathrm{M}-2 \mathrm{H}]^{+}, 430$ $\left[\mathrm{M}-\mathrm{OCH}_{3}\right]^{+}, 400,364[\mathrm{M}-\mathrm{Br}]^{+}, 350,322,283[\mathrm{M}-2 \mathrm{Br}]^{+}$, 255, 240, 222, $204[\mathrm{M}-3 \mathrm{Br}]^{+}, 189,173\left[\mathrm{M}-\mathrm{OCH}_{3}-\mathrm{Br}\right]^{+}$, 160, 148, 134, 127, 121, 86, 80, 73, 67, 61, 27, 17; Anal. calcd for $\mathrm{C}_{15} \mathrm{H}_{9} \mathrm{Br}_{3} \mathrm{O}: \mathrm{C}, 40.49 ; \mathrm{H}, 2.04$; found C, 40.40; H, 2.08 . 
1-Methoxy-2,9,10-tribromoanthracene (11) mp 164-165 ${ }^{\circ} \mathrm{C}$ (dichloromethane/hexane); ${ }^{1} \mathrm{H}$ NMR $\left(400 \mathrm{MHz}, \mathrm{CDCl}_{3}\right) \delta 8.86$ $(\mathrm{m}, 1 \mathrm{H}), 8.57(\mathrm{~m}, 1 \mathrm{H}), 8.38(\mathrm{~d}, J=9.6 \mathrm{~Hz}, 1 \mathrm{H}), 7.71(\mathrm{~d}, J=9.6$ $\mathrm{Hz}, 1 \mathrm{H}), 7.68(\mathrm{~m}, 2 \mathrm{H}), 3.91(\mathrm{~s}, 3 \mathrm{H}) ;{ }^{13} \mathrm{C} \mathrm{NMR}(100 \mathrm{MHz}$, $\left.\mathrm{CDCl}_{3}\right) \delta 152.8,132.8,131.8,131.3,131.2,129.1,128.4$, 128.3, 128.1, 126.7, 126.1, 124.8, 117.4, 116.8, 61.8; IR (KBr, $\left.\mathrm{cm}^{-1}\right)$ : 2991, 2976, 2931, 2834, 1698, 1670, 1652, 1617, 1591, $1539,1515,1446,1427,1375,1332,1291,1251,1144,1057$, 1032, 966, 929, 905, 796, 763, 744, 706, 651, 549, 532, 505, 481; Anal. calcd for $\mathrm{C}_{15} \mathrm{H}_{9} \mathrm{Br}_{3} \mathrm{O}$ : C, 40.49; H, 2.04; found: $\mathrm{C}$, 40.08; H, 2.15.

\section{Aromatization of compound $\mathbf{8}$}

A stirred solution of compound 8 (300 $\mathrm{mg}, 0.54 \mathrm{mmol})$ in dry and freshly distilled THF $(30 \mathrm{~mL})$ was combined with a solution of sodium methoxide $(73 \mathrm{mg}, 1.34 \mathrm{mmol})$ in freshly distilled THF $(20 \mathrm{~mL})$ under an argon atmosphere. The resulting reaction mixture was magnetically stirred for $12 \mathrm{~h}$ at $25{ }^{\circ} \mathrm{C}$. Ether $(50 \mathrm{~mL})$ was added to the reaction mixture and the resulting precipitate was washed with water $(3 \times 50 \mathrm{~mL})$ and dried over anhydrous sodium sulfate. The solvent was evaporated. ${ }^{1} \mathrm{H}$ NMR of the residue (217 $\mathrm{mg}$, total yield: 91\%) showed two products in a ratio of 45:55 for $\mathbf{1 0}$ and $\mathbf{1 1}$, respectively.

\section{The reaction of compound 8 with one equiva- lent of sodium methoxide}

To a stirred solution of compound $\mathbf{8}(200 \mathrm{mg}, 0.36 \mathrm{mmol})$ in dry and freshly distilled THF $(40 \mathrm{~mL})$ was added sodium methoxide (21 mg, $0.394 \mathrm{mmol}$ ) under argon atmosphere. The resulting reaction mixture was magnetically stirred for $1 \mathrm{~d}$ at $25^{\circ} \mathrm{C}$. Diethyl ether $(30 \mathrm{~mL})$ was added to the reaction mixture and the resulting precipitate was washed with water $(3 \times 30 \mathrm{~mL})$ and dried over anhydrous sodium sulfate. The solvent was evaporated. ${ }^{1} \mathrm{H}$ NMR of the residue $(132 \mathrm{mg})$ showed three products in a ratio of 56:13:1 for 14, 11 and $\mathbf{1 0}$, respectively, besides the remaining starting material 8 (conversion $70 \%$ ). The mixture was separated by thin layer chromatography to give pure compounds $\left(\mathrm{SiO}_{2}\right.$, hexane). Compound $\mathbf{1 4}$ was obtained in a yield of $14 \%$ (50 mg).

$\left(1 R^{*}, 4 S^{*}\right)-2,9,10$-Tribromo-1,4-dimethoxy-1,4-dihydroanthracene (14) $\mathrm{mp} 135-136{ }^{\circ} \mathrm{C}$ (dichloromethane/hexane); ${ }^{1} \mathrm{H}$ NMR (400 MHz, $\left.\mathrm{CDCl}_{3}\right) \delta 8.48(\mathrm{~m}, 2 \mathrm{H}), 7.70(\mathrm{~m}, 2 \mathrm{H}), 6.86$ $(\mathrm{d}, J=4 \mathrm{~Hz}, 1 \mathrm{H}), 5.82(\mathrm{~s}, 1 \mathrm{H}), 5.44\left(\mathrm{dd}, J=4 \mathrm{~Hz}, J_{1,4}=2 \mathrm{~Hz}\right.$, $1 \mathrm{H}), 3.23(\mathrm{~s}, 3 \mathrm{H}), 2.88(\mathrm{~s}, 3 \mathrm{H}) ;{ }^{13} \mathrm{C} \mathrm{NMR}\left(100 \mathrm{MHz}, \mathrm{CDCl}_{3}\right) \delta$ 133.2, 133.1, 132.8, 132.5, 131.6, 128.9, 129.0, 128.4, 128.2, 126.2, 125.8, 124.3, 76.0, 74.4, 53.9, 50.9; IR (KBr, cm $\left.{ }^{-1}\right)$ : 3056, 2989, 2931, 2823, 1670, 1563, 1479, 1457, 1438, 1344, $1305,1267,1251,1170,1037,946,921,900,852,755,701$, $651,644,624,597,572,553,514,453,426$; MS (APCI) $\mathrm{m} / \mathrm{z}$
$468.0\left[\mathrm{M}-\mathrm{OCH}_{3}+\mathrm{Na}-\mathrm{H}\right]^{+}, 444.9\left[\mathrm{M}-\mathrm{OCH}_{3}-\mathrm{H}\right]^{+}, 422.1$ $[\mathrm{M}-\mathrm{Br}+\mathrm{Na}]^{+}, 395.0[\mathrm{M}-\mathrm{Br}]^{+}, 366.1[\mathrm{M}-2 \mathrm{Br}+2 \mathrm{Na}+$ $3 \mathrm{H}]^{+}, 329\left[\mathrm{M}-\mathrm{OCH}_{3}-2 \mathrm{Br}+2 \mathrm{Na}-2 \mathrm{H}\right]^{+}, 227.1$; Anal. calcd for $\mathrm{C}_{16} \mathrm{H}_{13} \mathrm{Br}_{3} \mathrm{O}_{2}$ : C, 40.29; H, 2.75; found: $\mathrm{C}, 40.37 ; \mathrm{H}, 2.82$.

\section{Hydrolysis of hexabromide 6}

To a stirred solution of hexabromide $6(1000 \mathrm{mg}, 1.52 \mathrm{mmol})$ in acetone $(100 \mathrm{~mL})$ was added a solution of $\mathrm{AgClO}_{4} \cdot \mathrm{H}_{2} \mathrm{O}$ $(696 \mathrm{mg}, 3.35 \mathrm{mmol})$ in aqueous acetone $(6 \mathrm{~mL}$ acetone $+7 \mathrm{~mL}$ water) in the dark. The resulting mixture was stirred at $\mathrm{rt}$ for $2 \mathrm{~d}$ in the dark. After the reaction was complete (TLC), the AgBr precipitate was filtered off and the reaction mixture was diluted with methylene chloride $(30 \mathrm{~mL})$. The organic layer was washed with $\mathrm{H}_{2} \mathrm{O}(3 \times 30 \mathrm{~mL})$ and dried over $\mathrm{Na}_{2} \mathrm{SO}_{4}$. After removal of the solvent, the precipitate $(0.698 \mathrm{~g})$ was crystallized from methanol $(15 \mathrm{~mL}) .\left(1 S^{*}, 2 R^{*}, 3 S^{*}, 4 S^{*}\right)-2,3,9,10$-tetrabromo-1,2,3,4-tetrahydroanthracene-1,4-diol (17) was obtained in a yield of $80 \%(641 \mathrm{mg})$.

$\left(1 S^{*}, 2 R^{*}, 3 S^{*}, 4 S^{*}\right)-2,3,9,10$-Tetrabromo-1,2,3,4-tetrahydroanthracene-1,4-diol (17) $\mathrm{mp} 178-180{ }^{\circ} \mathrm{C}$; ${ }^{1} \mathrm{H} \mathrm{NMR}$ $\left(400 \mathrm{MHz}, \mathrm{CDCl}_{3}\right) \delta 8.49(\mathrm{~m}, 1 \mathrm{H}), 8.41(\mathrm{~m}, 1 \mathrm{H}), 7.71(\mathrm{~m}, 2 \mathrm{H})$, $5.90(\mathrm{~m}, 1 \mathrm{H}), 5.44(\mathrm{~m}, 1 \mathrm{H}), 5.26(\mathrm{~m}, 1 \mathrm{H}), 4.79(\mathrm{~m}, 1 \mathrm{H}), 3.10(\mathrm{~d}$, $\left.J_{4, \mathrm{OH}}=8.4 \mathrm{~Hz}, 1 \mathrm{H}\right), 2.90\left(\mathrm{~d}, J_{1, \mathrm{OH}}=4 \mathrm{~Hz}, 1 \mathrm{H}\right) ;{ }^{13} \mathrm{C} \mathrm{NMR}(100$ $\left.\mathrm{MHz}, \mathrm{CDCl}_{3}\right) \delta 133.6,133.4,133.1,131.6,129.3,129.2,128.8$, $128.5,128.0,127.3,74.6,69.9,53.2,48.9$; IR $\left(\mathrm{KBr}, \mathrm{cm}^{-1}\right)$ : 3509, 3405, 3068, 2983, 2931, 2904, 2825, 1716, 1617, 1567, $1479,1444,1407,1334,1247,1180,1157,1135,1097,1039$, $981,929,896,877,811,786,759,690,647,636,619,601,570$, $538,474,441$; MS (GC-MS/EI) $m / z 413$ [M - 2OH - Br $2 \mathrm{H}]^{+}, 334[\mathrm{M}-2 \mathrm{OH}-2 \mathrm{Br}-\mathrm{H}]^{+}, 255[\mathrm{M}-2 \mathrm{OH}-3 \mathrm{Br}]^{+}, 206$, $173[\mathrm{M}-2 \mathrm{OH}-4 \mathrm{Br}-2 \mathrm{H}]^{+}, 166,148,134,127,121,109,97$, 87, 73, 61, 49, 38, 30, 27, 17; Anal. calcd for $\mathrm{C}_{14} \mathrm{H}_{10} \mathrm{Br}_{4} \mathrm{O}_{2}: \mathrm{C}$, 31.74; H, 1.90; found C, 32.45; H, 2.01.

\section{Synthesis of 2,9,10-tribromo-1,4-dihydroan- thracene-1,4-diol (27)}

$\left(1 S^{*}, 2 R^{*}, 3 S^{*}, 4 S^{*}\right)-2,3,9,10$-Tetrabromo-1,2,3,4-tetrahydroanthracene-1,4-diol (17) (475 $\mathrm{mg}, 0.896 \mathrm{mmol})$ in dry THF $(20 \mathrm{~mL})$ was treated with sodium methoxide $(53.35 \mathrm{mg}$, $0.95 \mathrm{mmol})$ in dry THF $(15 \mathrm{~mL})$. The mixture was stirred at $\mathrm{rt}$ overnight. After the reaction was complete (TLC), the reaction was diluted with diethyl ether $(20 \mathrm{~mL})$ and washed with $\mathrm{H}_{2} \mathrm{O}(3$ $\times 20 \mathrm{~mL}$ ). The organic layer was dried over anhydrous sodium sulfate and concentrated under reduced pressure. After the residue was passed through a short $\mathrm{Al}_{2} \mathrm{O}_{3}$ (neutral, $15 \mathrm{~g}$ ) column, 2,9,10-tribromo-1,4-dihydroanthracene-1,4-diol (27) was recrystallized from methylene chloride/hexane $(20: 5 \mathrm{~mL})$, yield $276 \mathrm{mg}$ (69\%). The reaction was repeated with two equiv of $\mathrm{NaOMe}$ (106.7 mg, $1.9 \mathrm{mmol}$ ) under the same conditions and identical results were obtained. 
2,9,10-Tribromo-1,4-dihydroanhracene-1,4-diol (27) mp 141-142 ${ }^{\circ} \mathrm{C}$ (dichloromethane/hexane); ${ }^{1} \mathrm{H}$ NMR (400 MHz, $\left.\mathrm{CDCl}_{3}\right) \delta 8.42(\mathrm{~m}, 2 \mathrm{H}), 7.72(\mathrm{~m}, 2 \mathrm{H}), 6.69(\mathrm{~d}, J=4.4 \mathrm{~Hz}, 1 \mathrm{H})$, $5.80(\mathrm{~d}, J=6 \mathrm{~Hz}, 1 \mathrm{H}), 5.74(\mathrm{dd}, 1 \mathrm{H}), 3.28\left(\mathrm{~d}, J_{1, \mathrm{OH}}=6 \mathrm{~Hz}\right.$, $1 \mathrm{H}), 3.22\left(1 \mathrm{H}, \mathrm{d}, J_{4, \mathrm{OH}}=6 \mathrm{~Hz}\right) ;{ }^{13} \mathrm{C} \mathrm{NMR}\left(100 \mathrm{MHz}, \mathrm{CDCl}_{3}\right)$ $\delta 134.3,132.9,132.6,131.3,129.1,129.1,128.6,128.1,127.8$, 125.8, 125.7, 125.5, 70.2, 67.5; IR $\left(\mathrm{KBr}, \mathrm{cm}^{-1}\right)$ : 3540, 3338, 3064, 2952, 2873, 2840, 1673, 1567, 1479, 1403, 1344, 1311, 1247, 1166, 1118, 1051, 975, 900, 856, 835, 752, 700, 647, 545, 455; MS (GC-MS/EI) $m / z 413[\mathrm{M}-2 \mathrm{OH}]^{+}, 334[\mathrm{M}-2 \mathrm{OH}-$ $\mathrm{Br}]^{+}, 253[\mathrm{M}-2 \mathrm{OH}-2 \mathrm{Br}]^{+}, 206,173[\mathrm{M}-2 \mathrm{OH}-3 \mathrm{Br}]^{+}, 166$, 148, 134, 127, 121, 109, 97, 86, 73, 61, 49, 38, 30, 28, 17; Anal. calcd for $\mathrm{C}_{14} \mathrm{H}_{9} \mathrm{Br}_{3} \mathrm{O}_{2}$ : C, 37.46; $\mathrm{H}, 2.02$; found: $\mathrm{C}, 37.57$; $\mathrm{H}$, 2.28 .

\section{Synthesis of 2,9,10-tribromoanthracene-1,4- dione (28)}

To a solution of pyridinium chlorochromate $(300 \mathrm{mg}, 1.08$ mmol) in methylene chloride $(30 \mathrm{~mL})$ was added a solution of 2,9,10-tribromo-1,4-dihydroanthracene-1,4-diol (27) (222 mg, $0.504 \mathrm{mmol})$ in methylene chloride $(25 \mathrm{~mL})$. The mixture was stirred at ambient temperature for $3 \mathrm{~d}$. Reaction progress was monitored by TLC for consumption of the starting material. After the residue was filtered through a short silica gel (15 g) column eluting with dichloromethane $(200 \mathrm{~mL}), 2,9,10$-tribromoanthracene-1,4-dione (28) was crystallized from methylene chloride/hexane (2:1), yield $198 \mathrm{mg}(90 \%)$.

2,9,10-Tribromoanthracene-1,4-dione (28) $\mathrm{mp}$ 251.5-252.5 ${ }^{\circ} \mathrm{C} ;{ }^{1} \mathrm{H}$ NMR $\left(400 \mathrm{MHz}, \mathrm{CDCl}_{3}\right) \delta 8.81(\mathrm{~s}, 1 \mathrm{H})$, $8.74(\mathrm{~m}, 1 \mathrm{H}), 8.48(\mathrm{~m}, 1 \mathrm{H}), 7.84(\mathrm{~m}, 2 \mathrm{H}) ;{ }^{13} \mathrm{C} \mathrm{NMR}(100 \mathrm{MHz}$, $\left.\mathrm{CDCl}_{3}\right) \delta 177.0,174.3,146.1,134.7,134.1,132.5,131.8$, 131.6, 131.2, 130.3, 130.0, 129.7, 128.1, 124.3; IR ( $\left.\mathrm{KBr}, \mathrm{cm}^{-1}\right)$ : 3056, 2921, 2850, 1679, 1600, 1536, 1475, 1440, 1380, 1369, 1346, 1319, 1294, 1251, 1230, 1222, 1189, 1162, 1020, 1004, $919,875,862,757,701,669,601,566,549,420$; MS (APCI) $\mathrm{m} /$ $z 489.1\left[\mathrm{M}+\mathrm{Na}+\mathrm{NH}_{4}+3 \mathrm{H}\right]^{+}, 467.9[\mathrm{M}+\mathrm{Na}]^{+}, 446.0[\mathrm{M}+$ $\mathrm{H}]^{+}, 421.1,409.0\left[\mathrm{M}-\mathrm{Br}+\mathrm{NH}_{4}+\mathrm{Na}+3 \mathrm{H}\right]^{+}, 386.1[\mathrm{M}-\mathrm{Br}+$ $\left.\mathrm{NH}_{4}+3 \mathrm{H}\right]^{+}, 355.0,329.0,310.2[\mathrm{M}-2 \mathrm{Br}+\mathrm{Na}+2 \mathrm{H}]^{+}$, 271.0, 254.0, 227.1 [M $-3 \mathrm{Br}+\mathrm{Na}+\mathrm{H}]^{+}$, 149.1; Anal. Calcd for $\mathrm{C}_{14} \mathrm{H}_{5} \mathrm{Br}_{3} \mathrm{O}_{2}$ : C, 37.79; H, 1.13; found: C, 37.79; $\mathrm{H}$, 1.31 .

\section{Crystallography}

For crystal structure determination, single crystals of compounds 7 and 17 were used for data collection on a four-circle Rigaku R-AXIS RAPID-S diffractometer (equipped with a twodimensional area IP detector). The graphite-monochromated Mo $\mathrm{K} \alpha$ radiation $(\lambda=0.71073 \AA)$ and oscillation scan technique with $\Delta \omega=5^{\circ}$ for one image were used for data collection. The lattice parameters were determined by the least-squares methods on the basis of all reflections with $\mathrm{F}^{2}>2 \sigma\left(\mathrm{F}^{2}\right)$. Integration of the intensities, correction for Lorentz and polarization effects and cell refinement was performed with CrystalClear software [17]. The structures were solved by direct methods with SHELXS-97 [18] and refined by a full-matrix least-squares procedure with the program SHELXL-97 [18]. Hydrogen positions were found from difference Fourier maps and geometrical calculations, and refined using a riding model. The final difference Fourier maps showed no peaks of chemical significance.

Crystal data for 7: $\mathrm{C}_{16} \mathrm{H}_{14} \mathrm{Br}_{4} \mathrm{O}_{2}$, crystal system, space group: Monoclinic, $P 2_{1} / c$; unit cell dimensions: $a=12.8322$ (6) $\AA, b=$ 13.2320(7) $\AA, c=11.1619(5) \AA, \alpha=90^{\circ}, \beta=115.092(3)^{\circ}, \gamma=$ 90, volume: $1716.38(14) \AA^{3} ; Z=4$; calculated density: 2.159 $\mathrm{Mg} / \mathrm{m}^{3}$; absorption coefficient: $9.38 \mathrm{~mm}^{-1}$; $\mathrm{F}(000)$ : 1064; $\theta$-range for data collection $1.8-26.0^{\circ}$; refinement method: fullmatrix least-square on $F^{2}$; data/parameters: 2440/199; goodness-of-fit on $F^{2}$ : 1.527; final $\mathrm{R}$ indices $[\mathrm{I}>2 \sigma(\mathrm{I})]$ : $\mathrm{R}_{1}=0.048$, $\mathrm{wR}_{2}=0.0843$; $\mathrm{R}$ indices (all data): $\mathrm{R}_{1}=0.0776, \mathrm{wR}_{2}=0.093$; largest diff. peak and hole: 0.40 and -0.51 e $\AA^{-3}$; CCDC: 804575. Crystal data for 17: $\mathrm{C}_{14} \mathrm{H}_{10} \mathrm{O}_{2} \mathrm{Br}_{4}$, crystal system, space group: monoclinic, $P 2{ }_{1} / \mathrm{c}$; unit cell dimensions: $a=$ 7.9547(4), $b=11.9678(4), c=15.5015(6) \AA, \alpha=90^{\circ}, \beta=$ 101.14(3) ${ }^{\circ}, \gamma=90^{\circ}$; volume: $1447.92(2) \AA^{3} ; Z=4$; calculated density: $2.43 \mathrm{Mg} / \mathrm{m}^{3}$; absorption coefficient: $11.113 \mathrm{~mm}^{-1}$; $F(000)$ : $1000 ; \theta$-range for data collection $2.6-26.4^{\circ}$; refinement method: full-matrix least-square on $F^{2}$; data/parameters: 2168/ 183; goodness-of-fit on $F^{2}: 1.217$; final $R$ indices [I $\left.>2 \sigma(\mathrm{I})\right]: R_{1}$ $=0.069, \mathrm{w} R_{2}=0.088 ; R$ indices (all data): $R_{1}=0.102, \mathrm{w} R_{2}=$ 0.095 ; largest diff. peak and hole: 0.505 and -0.647 e $\AA^{-3}$; CCDC: 804289.

\section{Supporting Information}

Supporting information features copies of ${ }^{1} \mathrm{H}$ NMR and ${ }^{13} \mathrm{C}$ NMR spectra for all new compounds and crystallographic information files for compounds $\mathbf{7}$ and $\mathbf{1 7 .}$

\section{Supporting Information File 1}

NMR spectra of compounds 7, 8, 10, 11, 14, 17, 27 and 28.

[http://www.beilstein-journals.org/bjoc/content/ supplementary/1860-5397-7-118-S1.pdf]

\section{Supporting Information File 2}

Crystallographic information file for compound 7.

[http://www.beilstein-journals.org/bjoc/content/ supplementary/1860-5397-7-118-S2.cif] 


\section{Supporting Information File 3}

Crystallographic information file for compound 17.

[http://www.beilstein-journals.org/bjoc/content/

supplementary/1860-5397-7-118-S3.cif]

\section{Acknowledgements}

The authors thank Gaziosmanpaşa University Research Foundation (Grant No: 2006/13 and 2009/09) and The Scientific and Technological Research Council of Turkey (TUBITAK, Grant No: 105T426).

\section{References}

1. Cakmak, O.; Erenler, R.; Tutar, A.; Celik, N. J. Org. Chem. 2006, 71, 1795-1801. doi:10.1021/jo051846u

2. Cakmak, O.; Aydogan, L.; Berkil, K.; Gülcin, I.; Büyükgüngör, O. Beilstein J. Org. Chem. 2008, 4, No. 50. doi:10.3762/bjoc.4.50

3. Hökelek, T.; Tutar, A.; Cakmak, O. Acta Crystallogr., Sect. E 2002, 58, o10-012. doi:10.1107/S160053680102061X

4. Sajewicz, W.; Dlugosz, A. J. Appl. Toxicol. 2000, 20, 305-312. doi:10.1002/1099-1263(200007/08)20:4<305::AID-JAT659>3.0.CO;2-P

5. Hangartner, P. J.; Münch, R.; Meier, J.; Ammann, R.; Bühler, H. Endoscopy 1989, 21, 272-275. doi:10.1055/s-2007-1012967

6. de Witte, P.; Dreessen, M.; Lemli, J. Pharm. Acta Helv. 1991, 3, 70-73.

7. de Witte, P.; Cuveele, J.; Lemli, J. Planta Med. 1991, 57, 440-443. doi:10.1055/s-2006-960145

8. Marques, W. B.; dos Santos, H. S.; Pessoa, O. D. L.; Braz-Filho, R.; Lemos, T. L. G. Phytochemistry 2000, 55, 793-797. doi:10.1016/S0031-9422(00)00325-3

9. Chang, L. C.; Chávez, D.; Gills, J. J.; Fong, H. H. S.; Pezzuto, J. M.; Kinghorn, A. D. Tetrahedron Lett. 2000, 41, 7157-7162. doi:10.1016/S0040-4039(00)01205-3

10. El-Kemary, M. Can. J. Appl. Spectrosc. 1996, 41, 109-112.

11. Ihmels, H.; Meiswinkel, A.; Mohrschladt, C. J. Org. Lett. 2000, 2, 2865-2867. doi:10.1021/ol006291y

12. Bolognesi, M. L.; Lizzi, F.; Perozzo, R.; Brun, R.; Cavalli, A. Bioorg. Med. Chem. Lett. 2008, 18, 2272-2276. doi:10.1016/j.bmcl.2008.03.009

13. CS ChemOffice; Cambridge Scientific Computing Inc.: Cambridge, MA, USA.

14. Çelik, I.; Demirtas, I.; Akkurt, M.; Erenler, R.; Güven, K.; Çakmak, O. Cryst. Res. Technol. 2003, 38, 193-196. doi:10.1002/crat.200310022

15. Erenler, R.; Demirtas, I.; Buyukkidan, B.; Cakmak, O. J. Chem. Res. 2006, 753-757.

16. Tutar, A.; Cakmak, O.; Karakas, M.; Onal, A.; Ide, S. J. Chem. Res. 2004, 545-549.

17. CrystalClear ${ }^{T M}$ software; Rigaku Inc.: Texas, USA, 2005.

18. SHELX-97 program package, SHELXS97 and SHELXL97; Sheldrick, G. M.: University of Göttingen: Göttingen, Germany.

\section{License and Terms}

This is an Open Access article under the terms of the Creative Commons Attribution License

(http://creativecommons.org/licenses/by/2.0), which permits unrestricted use, distribution, and reproduction in any medium, provided the original work is properly cited.

The license is subject to the Beilstein Journal of Organic Chemistry terms and conditions:

(http://www.beilstein-journals.org/bjoc)

The definitive version of this article is the electronic one which can be found at:

doi:10.3762/bjoc. 7.118 